\title{
ANALISIS PENDAPATAN USAHATANI KENTANG DI DESA SINSINGON KECAMATAN PASSI TIMUR KABUPATEN BOLAANG MONGONDOW
}

\author{
Ferry Runturambi \\ Rine Kaunang \\ Theodora Maulina Katiandagho
}

\begin{tabular}{ll}
\hline Naskah diterima melalui Website Jurnal Ilmiah agrisosioekonomi@unsrat.ac.id & : Sabtu, 14 Desember 2019 \\
Disetujui diterbitkan & : Kamis, 09 Januari 2020 \\
\hline
\end{tabular}

\begin{abstract}
This study aims to analyze the income of potato farming in Sinsingon Village, Passi Timur District, Bolaang Mongondow Regency. This research was conducted in Sinsingon Village, Passi Timur District, Bolaang Mongondow Regency. Sampling in this study was carried out by simple random sampling, as many as 30 farmers who worked on potatoes. This research uses primary and secondary data. Primary data collection was carried out by direct interview with potato farmers in Sinsingon Village. Secondary data were collected from the Sinsingon Village Office and Passi Timur Sub-district Agriculutural Extension Office. Data analysis uses the formula for income and $R / C$ ratio. The results showed that the average potato farm receipts per farmer was $R p .18,746,000$ and the total average cost per farmer is $R p$. 10,891,458.33 and produce an average income per farmer of Rp. $7,854,541.67$ so as to obtain an $R / C$ ratio of $>1$ which is 1.72 , it means that the potato farming in Sinsingon Village, Passi Timur District is experiencing profit so that this business is worth the effort. ${ }^{* e p r m}{ }^{*}$
\end{abstract}

Keywords: Revenue Analysis; Potato; $R$ / C ratio

\begin{abstract}
ABSTRAK
Penelitian ini bertujuan untuk menganalisis pendapatan usahatani kentang di Desa Sinsingon, Kecamatan Passi Timur, Kabupaten Bolaang Mongondow. Penelitian ini dilakukan di Desa Sinsingon, Kecamatan Passi Timur, Kabupaten Bolaang Mongondow. Pengambilan sampel dalam penelitian ini dilakukan secara acak sederhana (simple random sampling), sebanyak 30 petani yang berusahatani kentang. Peneliitian ini menggunakan data primer dan sekunder. Pengambilan data primer dilakukan dengan cara wawancara langsung dengan petani kentang di Desa Sinsingon. Data sekunder dikumpulkan dari Kantor Desa Sinsingon dan Balai Penyuluhan Pertanian Kecamatan Passi Timur. Analisis data menggunakan rumus pendapatan dan $\mathrm{R} / \mathrm{C}$ rasio. Hasil penelitian menunjukkan bahwa penerimaan usahatani kentang rata-rata per petani adalah Rp. 18.746 .000 dan total biaya rata-rata per petani adalah Rp. 10.891.458,33 dan menghasilkan pendapatan rata-rata per petani Rp. 7.854.541,67 sehingga memperoleh keuntungan rasio $\mathrm{R} / \mathrm{C}>1$ yaitu 1,72 artinya usahatani kentang di Desa Sinsingon Kecamatan Passi Timur mengalami keuntungan sehingga usaha ini layak diusahakan. *eprm*
\end{abstract}

Kata kunci : Analisis Pendapatan; Kentang; R/C ratio

Agrisosioekonomi:

Jurnal Transdisiplin Pertanian (Budidaya Tanaman, Perkebunan, Kehutanan, Peternakan, Perikanan), Sosial dan Ekonomi 


\section{PENDAHULUAN}

\section{Latar Belakang}

Sektor pertanian memiliki peranan dalam pertumbuhan dan ketahanan ekonomi nasional. Dimana Indonesia memiliki sumber daya dasar pertanian yang mampu menghasilkan komoditi yang beragam dan jumlah yang banyak. Sehingga sampai pada saat ini sektor pertanian masih mendominasi perekonomian. Sebagai negara agraris yang sebagian besar penduduknya adalah kaum petani dan sebagian besar wilayahnya adalah daerah pedesaan, memiliki lahan pertanian yang luas, Indonesia seharusnya mampu mengandalkan pertanian sebagai sektor utama di negara ini. Tujuan pembangunan pertanian diarahkan untuk meningkatkan produksi pertanian guna memenuhi kebutuhan pangan dan kebutuhan industri dalam negeri, meningkatkan kebutuhan pangan dan kebutuhan industri dalam negeri, meningkatkan ekspor, meningkatkan pendapatan petani, memperluas kesempatan kerja dan mendorong pemerataan kesempatan berusaha (Soekartawi, 2003).

Pembangunan pertanian dihadapkan pada kondisi lingkungan strategis yang terus berkembang secara dinamis dan menjurus pada liberalisasi perdagangan internasional dan investasi. Menghadapi perubahan lingkungan strategis serta untuk memanfaatkan peluang yang ditimbulkannya, maka pembangunan pertanian lebih difokuskan pada komoditikomoditi unggulan yang dapat bersaing dipasar domestik maupun internasional. Kondisi ini menjadi dasar yang kuat bagi pemerintah untuk mempercepat reorientasi arah pembangunan sektor pertanian dari semata-mata peningkatan produksi pertanian modern yang berorientasi agribisnis tanpa merubah prioritas pokok, yaitu memantapkan swasembada pangan sebagai dasar utama menjaga stabilitas nasional (Daniel, 2002). Usaha peningkatan produksi dan pendapatan tergantung pada perilaku petani yang berusahatani. Berhasil tidaknya suatu usahatani dalam mencapai tujuan tergantung dari cari pengolahan cabang usahatani yang dikelolanya dimana petani berperan sebagai manager yang berkewajiban untuk mengambil keputusan mengenai pilihan dan harus mampu menentukan pola usahanai yang hendak diselenggarakan serta bagaimana cara mengolah usahatani tersebut.
Dalam pengelolaan suatu usahatani, petani mengupayakan agar hal yang diperoleh secara ekonomis menguntungkan, dimana biaya yang dikeluarkan dapat menghasilkan produksi yang maksimal. Sehingga pada akhirnya pendapatan petani meningkat, dan dengan meningkatnya pendapatan maka secara otomatis tingkat kesejahteraan petani tersebut akan meningkat.

Salah satu komoditi pertanian yang dapat membantu meningkatkan pendapatan dan kesejahteraan petani adalah kentang (Solanum tuberosum L.). Kentang adalah komoditas sayuran dengan kegunaan ganda, yaitu sebagai sayuran dan pengganti karbohidrat. Kentang digunakan sebagai makanan olahan, usaha rumah tangga, restoran siap saji, sampai industry besar untuk pembuatan tepung dan keripik. Pasar kentang bukan hanya di dalam negeri, tetapi juga di luar negeri sebagai komoditas ekspor yang menguntungkan (Duriat, 2006).

Tahun 1992 John Walukow menemukan alternatife bibit kentang yakni varietas 'Super John'. Tahun 1999 masyarakat membudidayakan di Sulawesi Utara khususnya diwilayah Modassi (Modoinding, Modayag, Passi), dan hingga saat ini petani telah berhasil membudidayakannya. Di Kecamatan Passi Timur ada beberapa desa yang baik untuk pertumbuhan tanaman kentang, salah satunya di Desa Sinsingon. Desa Sinsingon merupakan salah satu sentra produksi kentang di Sulawesi Utara dilihat dari data perkembangan produksi dan produktifitas. Tabel 1 menunjukkan perkembangan produksi dan produktifitas tanaman kentang di Kecamatan Passi Timur.

Tabel 1. Perkembangan Produksi dan Produktifitas Tanaman Kentang di Kecamatan Passi Timur

\begin{tabular}{|c|c|c|c|}
\hline \multirow[t]{2}{*}{ No } & \multirow[t]{2}{*}{ Desa } & \multicolumn{2}{|c|}{$\begin{array}{l}\text { Perkembangan Produktifitas Dan } \\
\text { Produksi Kentang (Ton) }\end{array}$} \\
\hline & & Produktivitas & Produksi \\
\hline 1 & Pangian Barat & - & - \\
\hline 2 & Pangian Tengah & - & - \\
\hline 3 & Pangian & - & - \\
\hline 4 & Poopo Barat & - & - \\
\hline 5 & Poopo Selatan & - & - \\
\hline 6 & Poopo & - & - \\
\hline 7 & Manembo & 3,5 & 140 \\
\hline 8 & Sinsingon Barat & 9 & 350 \\
\hline 9 & Sinsingon & 14,5 & 975 \\
\hline 10 & Sinsingon Timur & 12,5 & 175 \\
\hline 11 & Insil & 12,5 & 945 \\
\hline 12 & Insil Baru & 14,5 & 115 \\
\hline 13 & Mobuya & 6,5 & - \\
\hline
\end{tabular}


Tabel 1 menunjukkan bahwa di Kecamatan Passi Timur yang jumlah produksinya terbanyak adalah Desa Sinsingon, produktifitas mencapai 14,5 ton dan produksi mencapai 975 ton. ini berarti Desa Sinsingon juga berpengaruh dalam peningkatan produksi kentang di Kecamatan Passi Timur. sesuai data yang diperoleh dari kepala desa atau sangadi setempat bahwa $80 \%$ penduduk berprofesi sebagai petani kentang. walaupun produksi kentang di Desa Sinsingon cukup tinggi belum menjamin terjadinya peningkatan pendapatan petani, sebab banyak faktor yang mempengaruhinya.

\section{Rumusan Masalah}

Berdasarkan latar belakang yang dimaksud, maka menjadi masalah dalam penelitian ini adalah bagaimana pendapatan usahatani kentang di Desa Sinsingon, Kecamatan Passi Timur, Kabupaten Bolaang Mongondow?

\section{Tujuan Penelitian}

Penelitian ini bertujuan untuk menganalisis pendapatan usahatani kentang di Desa Sinsingon, Kecamatan Passi Timur, Kabupaten Bolaang Mongondow.

\section{Manfaat Penelitian}

Dapat memberikan informasi bagi pihakpihak yang memerlukannya untuk menambah wawasan dan pengetahuan yang lebih luas tingkat pendapatan usahatani kentang serta dapat digunakan sebagai bahan kajian untuk peningkatan usahatani dalam rangka mencapai keuntungan yang maksimal.

\section{METODE PENELITIAN}

\section{Waktu dan Tempat Penelitian}

Penelitian ini berlangsung selama 3 bulan sejak bulan Juni sampai bulan Agustus 2018. Tempat penelitian di Desa Buhias Kecamatan Wori Kabupaten Minahasa Utara.

\section{Tempat dan Waktu Penelitian}

Penelitian ini berlangsung selama 3 bulan sejak bulan September 2019 sampai November 2019, mulai dari persiapan sampai penyusunan laporan hasil penelitian.Tempat penelitian di Desa Sinsingon, Kecamatan Passi Timur, Kabupaten Bolaang Mongondow.

\section{Metode Pengumpulan Data}

Pengumpulan data yang digunakan dalam penelitian ini dengan menggunakan metode survey yang meliputi data primer dan data sekunder. Data primer diperoleh di lapangan tempat penelitian dalam hal ini masyakat Desa Sinsingon yang merupakan petani kentang, dengan cara mewawancarai langsung dengan menggunakan kuesioner. Data sekunder diperoleh dari instansi dan kantor desa. Data yang diperlukan dalam penelitian ini yaitu data tentang jumlah penduduk, mata pencaharian dan lainnya.

\section{Metode pengambilan sampel}

Objek dalam penelitian ini adalah petani kentang di Desa Sinsingon. Pengambilan sampel dalam penelitian ini dilakukan secara acak sederhana (simple random sampling), sebanyak 30 petani yang berusahatani kentang.

\section{Konsepsi pengukuran variabel}

1. Karakteristik petani:

a. Umur petani (Tahun)

b. Tingkat pendidikan (SD, SMP, SMA, PT)

c. Jumlah anggota keluarga (orang)

d. Pengalaman berusahatani kentang (tahun)

2. Variabel utama dalam penelitian ini meliputi:

1) Biaya produksi yaitu biaya yang dikeluarkan petani dalam satu kali proses produksi, meliputi biaya tetap dan biaya tidak tetap.

a. Biaya tetap yaitu biaya yang tidak berhubungan langsung dengan barang yang diproduksi yaitu meliputi:

1. Pajak tanah, besarnya sesuai dengan luas dan daya guna lahan ( $\mathrm{Rp} / \mathrm{thn})$

2. Penyusutan alat, yaitu nilai penggunaan cangkul, sekop dan hand sprayer yang disebabkan oleh pemakaiannya selama proses produksi berlangsung (Rp). Perhitungan penyusutan alat menggunakan rumus: $\mathrm{D}(\mathrm{Rp})=$ Harga awal Rp-Harga akhir (Rp)Waktu pakai (Thn)

b. Biaya tidak tetap (variabel) yaitu biaya yang langsung mempengaruhi besarnya produksi yang dihasilkan terdiri dari:

1. Harga, yaitu harga yang berlaku ditingkat petani $(\mathrm{Rp} / \mathrm{kg})$. 
2. Tenaga kerja, yaitu tenaga kerja yang digunakan dan jenis tenaga kerja serta sumber sumber tanaga kerja. Jumlah tenaga kerja diukur dalam hari orang kerja (HOK).

3. Benih, yaitu banyaknya benih yang digunakan oleh petani dalam usahataninya ( $\mathrm{Rp} / \mathrm{kg})$.

4. Pupuk, yaitu banyaknya pupuk yang digunakan oleh petani dalam usahatani nya $(\mathrm{Rp} / \mathrm{kg})$.

5. Pestisida, yaitu banyaknya pestisida yang digunakan olah petani dalam usahataninya $(\mathrm{Rp} / \mathrm{kg})$.

2) Luas lahan, yaitu luas lahan keseluruhan yang digunakan dalam usahatani kentang (Ha).

3) Produksi, yaitu jumlah produksi kentang yang diperoleh dalam satu kali tanam ( Rp/kg).

4) Penerimaan adalah perkalian antara produksi dengan harga jual $(\mathrm{Rp} / \mathrm{kg})$.

5) Pendapatan usahatani adalah selisih antara penerimaan dan pengeluaran $(\mathrm{Rp})$.

\section{Metode Analisis Data}

Analisis data yang digunakan dalam penelitian ini adalah analisis deskriptif dan disajikan dalam bentuk tabel. Untuk menghitung tingkat keuntungan ekonomis kentang akan digunakan analisis penerimaan, biaya, pendapatan, kemudian dilanjutkan dengan analisis return cost ratio.

a) Penerimaan usahatani adalah perkalian antara produksi yang diperoleh dengan harga jual. Peryataan ini dapat di tulis sebagai berikut.

$$
\mathrm{TR}=\mathrm{Y} \cdot \mathrm{PY}
$$

Dimana:

TR $=$ Total Penerimaan

$\mathrm{Y}=$ Produksi yang diperoleh dalam usahatani

Py = Harga yang berlaku

b) Biaya Total adalah jumlah uang yang dikeluarkan untuk memproduksi kentang dengan rumus:

$$
\mathrm{TC}=\mathrm{FC}+\mathrm{VC}
$$

Dimana:

$\mathrm{TC}=$ Total Cost (Total Pengeluaran)

$\mathrm{FC}=$ Fixed Cost (Biaya Tetap)

$\mathrm{VC}=$ Variabel Cost (Biaya Variabel)

c) Pendapatan adalah selisih antara penerimaan dan semua biaya dengan rumus:

$$
\mathrm{Pd}=\mathrm{TR}-\mathrm{TC}
$$

Dimana:

$\mathrm{Pd}=$ Pendapatan Usahatani

$\mathrm{TR}=$ Total revenue $($ Total Penerimaan $)$

$\mathrm{TC}=$ Total cost $($ Total Pengeluaran)

d) Return cost ratio adalah perbandingan antara penerimaan dengan biaya-biaya yang dikeluarkan selama proses produksi hingga menghasilkan produk. Dengan rumus:

$$
\mathrm{a}=\mathrm{R} / \mathrm{C}
$$

Dimana:

$\mathrm{a}=$ Return cost ratio

$\mathrm{R}=$ Penerimaan

$\mathrm{C}=$ Cost

Secara teoritis dengan ratio $\mathrm{R} / \mathrm{C}$ :

$>1$ Usahatani tersebut mengalami keuntungan

$\neq 1$ Artinya usahatani tidak untung dan tidak rugi

$<1$ artinya usahatani mengalami kerugian.

\section{HASIL DAN PEMBAHASAN}

\section{Deskripsi Lokasi Penelitian}

\section{Keadaan Geografis Lokasi Penelitian}

Desa Sinsingon merupakan salah satu desa yang terletak di Kecamatan Passi Timur, Kabupaten Bolaang Mongondow, Provinsi Sulawesi Utara. Luas wilayah Desa Sinsingon $21.700 \mathrm{Ha}$, jarak dengan ibukota kabupaten/kota $89 \mathrm{~km}$. Wilayah ini merupakan dataran tinggi \pm 1.100 - $1300 \mathrm{mdpl}$, jenis tanah adalah Andosol dan Letosol dengan topografi landai sampai berbukit, $\mathrm{pH}$ tanah netral. Suhu terendah berkisar $15^{\circ} \mathrm{C}$, tertinggi $32^{\circ} \mathrm{C}$ dan rata-rata $20^{\circ} \mathrm{C}$.

Penduduk Desa Sinsingon berjumlah 715 jiwa (347 laki-laki dan perempuan 368) termasuk dalam 233 kepala keluarga (Kantor Desa Sinsingon) serta sebagian besar penduduk bermata pencaharian sebagai petani. Batas wilayah administratif. Desa Sinsingon sebagai berikut:
a. Sebelah Utara : Desa Sinsingon Timur
b. Sebelah Selatan : Desa Sinsingon Barat
c. Sebelah Barat : Hutan Lindung
d. Sebelah Timur : Perkebunan Sinsingon Timur

\section{Karakteristik Responden}

\section{Umur Petani}

Umur petani akan mempengaruhi kemampuan fisik dalam bekerja. Petani yang masih muda dan sehat akan berproduktivitas lebih besar dari pada petani yang sudah tua. Dari 30 
responden petani kentang di Desa Sinsingon Kecamatan Passi Timur Kabupaten Bolaang Mongondow menunjukkan bahwa kisaran umur petani adalah 27 - 57 tahun, umur petani dapat dilihat pada Tabel 2.

\begin{tabular}{lcc}
\multicolumn{3}{c}{ Tabel 2. Jumlah Petani Menurut Golongan Umur } \\
\hline $\begin{array}{c}\text { Umur Petani } \\
\text { (tahun) }\end{array}$ & $\begin{array}{c}\text { Jumlah Petani } \\
\text { (orang) }\end{array}$ & Persentase $(\%)$ \\
\hline $27-36$ & 5 & 16,7 \\
$37-46$ & 11 & 36,6 \\
$47-56$ & 9 & 30 \\
$>57$ & 5 & 16,7 \\
\hline Jumlah & 30 & 100 \\
\hline \multicolumn{2}{l}{ Sumber : Diolah dari data primer, 2019 }
\end{tabular}

Tabel 2 menunjukkan bahwa responden petani berumur produktif. Hal ini dilihat dari jumlah petani (responden) dengan usia 27-36 tahun sebanyak 5 (lima) orang $(16,7 \%), 37-46$ tahun sebanyak 11 (sebelas) orang $(36,6 \%), 47$ 56 tahun sebanyak 9 (sembilan) orang (30\%) dan interval lebih dari 57 tahun sebanyak 5 (lima) orang $(16,7 \%)$. Pada umumnya petani responden berumur 37-46 tahun atau 36,6 persen dari keseluruhan responden, kategori umur tersebut secara fisik tergolong masih kuat untuk bekerja mengelola usahatani kentang.

\section{Tingkat Pendidikan}

Pendidikan merupakan faktor yang sangat penting bagi peningkatan SDM. Adanya pendidikan yang memadai dapat meningkatkan kecakapan petani dalam mengusahakan usahataninya sehingga dapat menguntungkan dan meningkatkan taraf hidupnya. Pendidikan berpengaruh juga terhadap kemampuan berpikir dan beradaptasi dengan lingkungannya.

Tabel 3. Jumlah Petani Menurut Tingkat Pendidikan

\begin{tabular}{lcc}
\hline Pendidikan & Jumlah petani (orang) & Persentase (\%) \\
\hline SD & 6 & 20 \\
SMP & 12 & 40 \\
SMA & 10 & 33 \\
S-I & 2 & 7 \\
\hline Jumlah & 30 & 100 \\
\hline
\end{tabular}

Sumber : Diolah dari data primer, 2019

Tabel 3 menunjukkan bahwa pendidikan petani di Desa Sinsingon berjenjang dari sekolah dasar (SD) sampai strata 1 (S-I). Persentase terbesar adalah berpendidikan SMP, yaitu 12 petani atau 40\%, berpendidikan SMA sebanyak 10 petani atau 33\%, berpendidikan SD sebanyak 6 petani atau 20\%, dan 2 petani atau $7 \%$ berpendidikan S-I.

\section{Jumlah Tanggungan Anggota Keluarga}

Tanggungan keluarga petani meliputi istri, anak-anak dan anggota keluarga lainnya yang bersama-sama dengan petani.

Tabel 4. Jumlah Tanggungan Anggota Keluarga Petani

\begin{tabular}{lcc}
\hline $\begin{array}{c}\text { Jumlah anggota } \\
\text { keluarga (orang) }\end{array}$ & $\begin{array}{c}\text { Jumlah petani } \\
\text { (orang) }\end{array}$ & Persentase (\%) \\
\hline 0 & 1 & 3 \\
$1-2$ & 14 & 47 \\
$3-4$ & 15 & 50 \\
\hline Jumlah & 30 & 100 \\
\hline Sumber : Diolah dari data primer, 2019
\end{tabular}

Tabel 4 menunjukkan bahwa sebagian besar petani mempunyai jumlah tanggungan 3 4 orang, dengan persentase jumlah petani adalah $50 \%$ atau berjumlah 15 orang petani.

\section{Pengalaman Berusahatani Kentang}

Pengalaman berusahatani merupakan salah satu faktor penentu keberhasilan usahatani. Petani yang sudah berpengalaman dalam usahatani cenderung lebih terampil dalam mengelola usaha taninya. Berdasarkan pengalaman tersebut, petani dapat meningkatkan produksi kentang melalui komunikasi antar petani. Pengalaman berusahatani kentang dapat dilihat pada Tabel 5.

Tabel 5. Pengalaman Berusahatani Kentang

\begin{tabular}{lccc}
\hline \multirow{2}{*}{ No } & Pengalaman (Tahun) & \multicolumn{2}{c}{ Jumlah Responden (Orang) } \\
\cline { 3 - 4 } & & Jumlah & Persentase (\%) \\
\hline 1 & $5-20$ & 18 & 60 \\
2 & $21-35$ & 10 & 33 \\
3 & $36-50$ & 2 & 7 \\
\hline \multicolumn{2}{l}{ Jumlah } & 30 & 100 \\
\hline \multicolumn{2}{l}{ Sumber : Diolah dari data primer, 2019}
\end{tabular}

Tabel 5 menunjukkan bahwa pengalaman petani bekerja sebagai petani kentang 5 sampai 20 tahun sebanyak 18 responden dengan presentase $60 \%$, 21 sampai 35 tahun sebanyak 10 responden dengan presentase $33 \%$, dan 36 sampai 50 tahun sebanyak 2 responden dengan presentase $7 \%$. Tingkat pengalaman berusahatani kentang bagi sebagian besar petani sudah cukup berpengalaman sehingga dalam menjalankan aktifitasnya sebagai petani kentang cukup baik dan tanaman kentang sudah cukup produktif. Dalam halnya bertani, petani mengenal tanaman kentang sudah lama dan teknik budidaya kentang sudah turun temurun. 
Tabel 6. Luas Lahan Petani Kentang di Desa Sinsingon

\begin{tabular}{lcr}
\hline Luas Lahan $(\mathrm{Ha})$ & Jumlah Petani (orang) & Persentase $(\%)$ \\
\hline$<0,25$ & 14 & 47 \\
$0,26-0,75$ & 13 & 43 \\
$0,76-1,25$ & 2 & 7 \\
$>1,26$ & 1 & 3 \\
\hline Jumlah & 30 & 100 \\
\hline Sumber : Diolah dari data primer, 2019 &
\end{tabular}

Tabel 6 menunjukkan bahwa jumlah petani terbanyak dalam mengelolah lahan untuk usahatani kentang pada luas lahan $<0,25$ ha yaitu sebanyak 14 orang, atau sekitar $47 \%$. Sedangkan jumlah petani kentang paling sedikit yaitu pada luas lahan $>1,26$ ha sebanyak 1 orang atau sekitar 3\%. Ratarata penggunaan lahan pada usahatani kentang di Desa Sinsingon adalah 0,36 ha, sedangkan untuk status kepemilikan lahan usahatani kentang adalah milik sendiri dari masingmasing petani.

\section{Status Kepemilikan Lahan}

Status kepemilikan lahan sangat berpengaruh terhadap tingkat pendapatan petani karena status kepemilikan lahan juga mempengaruhi biaya yang akan dikeluarkan oleh petani. Kepemilikan lahan dapat dilihat pada Tabel 7.

Tabel 7. Status Kepemilikan Lahan Petani Kentang di Desa Sinsingon

\begin{tabular}{llcr}
\hline No & Status Lahan & \multicolumn{2}{c}{ Jumlah Responden (Orang) } \\
\cline { 3 - 4 } & & Jumlah & Persentase (\%) \\
\hline 1 & Milik Sendiri & 30 & 100 \\
2 & Pinjam & - & - \\
\hline Jumlah & 30 & 100 \\
\hline
\end{tabular}

Sumber : Diolah dari data primer, 2019.

Tabel 7 menunjukkan kepemilikan lahan petani kentang adalah milik sendiri dengan presentase $100 \%$. Para pertani responden menggarap lahannya dengan membudidaya-kan berbagai macam jenis tanaman seperti kentang, bawang daun, wortel, tomat, labu kuning, dan sebagainya.

\section{Produksi}

\section{Jumlah Produksi}

Produksi merupakan suatu kegiatan untuk meningkatkan manfaat dengan cara mengkombinasikan faktor-faktor produksi; tanah, tenaga kerja, modal dan manajemen.
Banyaknya produksi kentang yang dihasilkan oleh petani bervariasi. Rata-rata produksi kentang yang dihasilkan oleh setiap petani di Desa Sinsingon adalah $2678 \mathrm{Kg}$ dimana jumlah produksi tertinggi yakni $10.001 \mathrm{Kg}$ didapati 1 orang petani atau $3 \%$. Sebagian besar petani kentang memproduksi 1.001-5.000 Kg, yakni sebanyak 22 orang petani atau sekitar $74 \%$, sedangkan jumlah produksi $<1.000 \mathrm{Kg}$, sebanyak 4 orang petani atau $13 \%$ dan jumlah produksi diantara 5.001-10.000 $\mathrm{Kg}$, sebanyak 3 orang atau hanya $10 \%$ dari jumlah responden. Jumlah produksi dapat dilihat pada Tabel 8.

Tabel 8. Volume Produksi Usahatani Kentang Petani di Desa Sinsingon

\begin{tabular}{|c|c|c|}
\hline $\begin{array}{c}\text { Jumlah Produksi } \\
(\mathrm{Kg})\end{array}$ & $\begin{array}{c}\text { Jumlah Petani } \\
\text { (Orang) }\end{array}$ & $\begin{array}{c}\text { Persentase } \\
(\%)\end{array}$ \\
\hline$<1.000$ & 4 & 13 \\
\hline $1.001-5.000$ & 22 & 74 \\
\hline $5.001-10.000$ & 3 & 10 \\
\hline$>10.001$ & 1 & 3 \\
\hline Jumlah & 30 & 100 \\
\hline
\end{tabular}

Volume produksi merupakan faktor penentu besarnya pendapatan yang diterima oleh petani kentang itu sendiri. Semakin besar volume produksi yang dihasilkan, maka akan semakin tinggi pula pendapatan para petani kentang di Desa Sinsingon.

\section{b. Harga Jual}

Harga merupakan persetujuan antara pembeli dan penjual dalam suatu produk tertentu, dalam hal ini petani merupakan penjual komoditi kentang. Harga jual adalah variabel paling utama dalam menentukan besarnya penerimaan suatu usahatani. Harga jual pada tingkat petani sama yaitu $\mathrm{Rp} 7.000 / \mathrm{Kg}$.

\section{Penerimaan Usahatani Kentang}

Penerimaan usahatani kentang adalah perkalian antara jumlah produksi kentang dan harga jual ditingkat petani. Oleh karena itu besarnya penerimaan usahatani kentang tergantung pada jumlah produksi dan harga tersebut. Hasil penelitian menunjukkan bahwa besarnya penerimaan usahatani kentang di Desa Sinsingon berkisar antara Rp.3.360.000,- sampai dengan Rp.86.940.000,- sedangkan rata-rata per petani Rp.18.746.000,- dan rata-rata per hektar adalah Rp.51.349.525,2-. 


\section{Biaya Produksi Usahatani Kentang}

Biaya produksi yaitu biaya yang dikeluarkan petani dalam satu kali proses produksi, meliputi biaya tetap dalam usahatani kentang yaitu pajak tanah serta penyusutan alat sedangkan biaya tidak tetap yaitu benih, pupuk, pestisida dan tenaga kerja.

\section{Biaya Tetap}

a. Pajak

Pajak yaitu biaya tanah yang di bayar per tahun. Dalam hal ini biaya produksi dihitung per satu musim tanam. Menurut hasil penelitian, biaya pajak ditanggung oleh pemilik lahan sendiri yaitu sebanyak 30 petani. Pajak merupakan salah satu unsur biaya yang perlu diperhitungkan petani.

\section{b. Peralatan}

Dalam pengelolaan usahatani kentang, peralatan yang diperlukan yakni cangkul, sekop dan hand sprayer. Seluruh petani yang ada di Desa Sinsingon memiliki dan menggunakan tiga macam alat tersebut, setiap tenaga kerja yang disewa dalam usahatani kentang menggunakan alatnya masingmasing. Oleh sebab itu perhitungan biaya penyusutan hanya alat milik petani.

Biaya tetap yaitu biaya yang tidak berhubungan langsung dengan barang yang di produksi, yaitu pajak serta penyusutan peralatan. Penyusutan yang dihitung adalah berdasarkan alat-alat milik sendiri. Biaya penyusutan alat dapat dilihat pada Tabel 9.

\begin{tabular}{lcr} 
Tabel 9. & \multicolumn{2}{c}{ Rata-Rata Biaya Tetap Pajak dan Penyusutan } \\
& Peralatan Usahatani Kentang di Desa Sinsingon \\
\hline Biaya Tetap & Rata-rata & Rata-rata \\
& Per Petani (Rp) & Per Hektar (Rp) \\
\hline Pajak & $6.491,66$ & $17.782,14$ \\
Cangkul & 42.000 & $115.047,48$ \\
Sekop & 23.000 & $63.002,19$ \\
Hand Sprayer & 180.000 & $493.060,62$ \\
\hline Jumlah & $6.736,66$ & $688.892,4$ \\
\hline
\end{tabular}

Sumber : Diolah dari data primer, 2019

Tabel 9 menunjukkan bahwa rata-rata biaya pajak dan penyusutan peralatan pada usahatani kentang di Desa Sinsingon adalah Rp. 251.492 per petani dan Rp. 688.892 per hektar. Biaya penyusutan diatas di peroleh dari pengurangan harga awal dan harga akhir dibagi dengan waktu pakai, sedangkan perhitungan pajak diperoleh dari pajak lahan pertahun dibagi dengan jangka waktu satu kali proses produksi.

\section{a. Bibit}

\section{Biaya Tidak Tetap (Variabel)}

Bibit merupakan faktor produksi yang penting karena menjadi cikal bakal tanaman kentang. Benih kentang yang digunakan oleh petani di Desa Sinsingon sampai saat ini adalah varietas Super John, rata-rata benih yang ditanam adalah 1.519,2 Kg/ha.

\section{b. Tenaga Kerja}

Sebagian petani kentang di Desa Sinsingon menggunakan tenaga kerja yang merupakan berasal dari keluarga, namun dalam tahap-tahap tertentu petani mengambil tenaga kerja diluar keluarga, seperti pengolahan lahan, penanaman dan panen, apalagi jika hasil panen usahataninya banyak.

Upah tenaga kerja yang berlaku di Desa Sinsingon, Kecamatan Passi Timur terbagi dua jenis yaitu, untuk upah tenaga kerja pada pengolahan lahan Rp. 100.000,-(HOK) dan untuk upah tenaga kerja pada penanaman sampai panen Rp. 70.000,-(HOK).

\section{c. Pengolahan Lahan}

Petani kentang di Desa Sinsingon melakukan pengolahan lahan atau bedengan sebelum penanaman. Upah tenaga kerja pada tahap ini Rp 100.000,-(HOK), biasanya tenaga kerja yang dipakai pada tahap pengolahan lahan sekitar \pm 36 orang per hektar. Total biaya pengolahan lahan sekitar Rp.3.670.562,-/ha.

\section{d. Penanaman}

Tahap penanaman dilakukan setelah pengolahan lahan. Upah tenaga kerja pada tahap ini Rp 70.000,-(HOK), biasanya tenaga kerja yang di pakai pada tahap penanaman sekitar \pm 21 orang per hektar. Total biaya penanaman sekitar Rp.1.480.095,-/ha. 


\section{e. Penyemprotan}

Penyemprotan merupakan salah satu faktor penting dalam menentukan produksi kentang, penyemprotan dilakukan pada saat tanaman kentang berumur 15-75 HST dengan interval penyemprotan 7-10 hari. Upah tenaga kerja pada tahap ini Rp 70.000,-(HOK), biasanya tenaga kerja yang di pakai pada tahap penyemprotan sekitar \pm 19 orang per hektar. Total biaya penyemprotan sekitar Rp.1.344.959,-/ha.

\section{f. Pestisida}

Suatu usahatani gangguan hama dan penyakit tumbuhan menjadi masalah yang sangat mempengaruhi penurunan produktivitas hasil panen, begitu pula yang dialami para petani kentang yang ada di Desa Sinsingon. Pestisida yang biasanya digunakan adalah manzete, amistartop, antracol, bayfoland, pertrovita, abacel, spermetrin disesuaikan dengan serangan $\mathrm{H} / \mathrm{P}$ tersebut. Penyemprotan pestisida dilakukan pada saat pagi hari pukul 06.00-09.00 dan pada sore hari dilakukan pada pukul 15.0018.00 dalam keadaan cuaca mendung. Dalam satu kali musim tanam penyemprotan pestisida biasanya dilakukan 4-7 kali dan penyemprotan dihentikan pada saat 20 hari sebelum tanaman kentang akan dipanen. Rata-rata penggunaan pestisida Rp. 551.800,-/petani dan Rp. 1.511.505,/ha.

\section{g. Pemupukan}

Pemupukan adalah faktor penting dalam upaya peningkatan hasil produksi suatu usahatani. Dalam pertanian dikenal dua jenis pupuk yaitu pupuk organik dan non organik. Sebagian besar Usahatani kentang di Desa Sinsingon masih menggunakan jenis pupuk kimia / non organik. Pemupukan kentang dilakukan dalam III tahap yaitu, tahap I dilakukan pada saat tanaman berumur 7 HST. Sedangkan pemupukan ke II dilakukan 20 HST. Pemupukan ke III dilakukan 15 hari setelah pemupukan ke II. Perlu diketahui bahwa pada tahap I pupuk yang digunakan adalah pupuk organik yaitu pupuk kandang. Pada tahap II dan tahap III pupuk yang digunakan adalah pupuk kimia dengan campuran dari pupuk Urea, Ponska dan SP, disesuaikan dengan kebutuhan tanaman kentang. Rata-rata biaya penggunaan pupuk Rp.210.000,-/petani dan Rp.575.237,-/ha.

\section{h. Penimbunan}

Pada tahap penimbunan ini dilakukan saat tanaman kentang brumur 20-30 HST. Upah tenaga kerja pada tahap ini Rp 70.000,-(HOK), biasanya tenaga kerja yang di pakai pada tahap penimbunan sekitar \pm 21 orang per hektar. Total biaya penimbunan sekitar Rp.1.412.527,39/ha.

i. Panen

Panen biasanya dilakukan pada saat tanaman kentang telah mengering atau usia tanaman sudah berumur 100-110 hari setelah tanam (HST). Upah tenaga kerja pada tahap ini Rp 70.000,-(HOK), biasanya tenaga kerja yang di pakai pada tahap pemanenan sekitar \pm 21 orang per hektar. Total biaya panen sekitar Rp.2.810.446,-/ha.

j. Transportasi

Usahatani kentang di Desa Sinsingon transportasi sangat penting untuk mengangkut hasil panen dari kebun ke rumah petani. Satu karung kentang di bayar Rp.10.000,- biaya transportasi yang dipakai pada tahap ini sekitar Rp. 1.243.608,473 -/ha.

Tabel 10. Rata-rata Biaya Variabel Usahatani Kentang di Desa Sinsingon

\begin{tabular}{|c|c|c|}
\hline Biaya variabel & $\begin{array}{c}\text { Rata-rata } \\
\text { Per Petani (Rp) }\end{array}$ & $\begin{array}{c}\text { Rata-rata } \\
\text { Per Hektar (Rp) }\end{array}$ \\
\hline Bibit & $3.883 .333,3$ & 10.637 .327 \\
\hline Pengolahan & 1.340 .000 & $3.670 .562,454$ \\
\hline Lahan & & \\
\hline Penanaman & $540.333,33$ & 1.480 .095 \\
\hline Penyemprotan & 491.000 & $1.344 .959,825$ \\
\hline Pestisida & 551.800 & 1.511 .505 \\
\hline Pemupukan & 210.000 & $575.237,4$ \\
\hline Pupuk & $1.327 .833,33$ & $3.637 .235,21$ \\
\hline Penimbunan & $515.666,667$ & $1.412 .527,39$ \\
\hline Panen & 1.026 .000 & 2.810 .446 \\
\hline Transportasi & 454.000 & $1.243 .608,473$ \\
\hline Biaya Lainnya & 300.000 & $821.767,7$ \\
\hline Jumlah & $10.639 .966,63$ & $29.145 .271,45$ \\
\hline
\end{tabular}

Tabel 10 menunjukkan rata-rata biaya variabel usahatani kentang per petani adalah Rp. 10.639.966,63 sedangkan rata-rata per hektar adalah Rp. 29.145.271,45. Petani kentang selama satu kali proses produksi mengeluarkan biaya untuk bibit sebesar Rp.3.883.333,3- biaya tenaga kerja sebesar Rp. 4.877.000 biaya pupuk sebesar Rp. 1.327.833,33- biaya pestisida sebesar Rp. $551.800,-$. 


\section{Total Biaya Produksi}

Total biaya produksi adalah jumlah dari biaya tetap ditambah dengan jumlah biaya variabel, sedangkan dalam penelitian ini yaitu jumlah dari biaya pajak dan penyusutan ditambah dengan biaya pengadaan benih, tenaga kerja, pemeliharaan dan transportasi.

Tabel 11. Rata-rata Biaya Produksi Kentang di Desa Sinsingon

\begin{tabular}{llrr}
\hline No. & Jenis Biaya & $\begin{array}{r}\text { Rata-rata } \\
\text { PerPetani } \\
(\mathrm{Rp})\end{array}$ & $\begin{array}{r}\text { Rata-rata } \\
\text { PerHektar } \\
(\mathrm{Rp})\end{array}$ \\
\hline $1 \quad$ Biaya tetap & & \\
& - Pajak dan & $251.491,7$ & $688.892,4$ \\
& Penyusutan & & \\
$\quad$ Alat & & \\
2iaya variabel & $3.883 .333,3$ & 10.637 .327 \\
& - Bibit & 4.877 .000 & 13.359 .204 \\
& -Tenaga kerja & 551.800 & 1.511 .505 \\
& - Pestisida & $1.327 .833,33$ & $3.637 .235,21$ \\
\hline & - Pupuk & & \\
\hline & Jumlah & $10.891 .458,33$ & $29.834 .162,71$ \\
\hline Sumber : Diolah dari data primer, 2019.
\end{tabular}

Rata-rata total biaya yang harus dikeluarkan oleh setiap petani dalam satu kali musim tanam adalah sebesar Rp.10.891.45 8,33 sedangkan rata-rata biaya produksi perhektar adalah Rp. 29.834.162,71 untuk pengeluaran biaya terbanyak terdapat pada biaya tenaga kerja.

\section{Pendapatan Usahatani Kentang}

Pendapatan merupakan hasil dari suatu usaha yang akan dinilai dari biaya yang dikeluarkan dan penerimaan yang diperoleh. Pendapatan usahatani kentang di Desa Sinsingon yaitu sebagai produk total usahatani dalam jumlah tertentu, baik yang dijual maupun yang tidak dijual. Pendapatan adalah selisih antara penerimaan dan semua biaya dengan rumus, yaitu:

a. $\mathrm{TR}=\mathrm{Y} . \mathrm{PY}$

$$
\begin{aligned}
& =2.678 \times 7.000 \\
& =18.746 .000
\end{aligned}
$$

b. $\quad \mathrm{TC}=\mathrm{FC}+\mathrm{VC}$

$$
\begin{aligned}
& =251.491,67+10.639 .966,67 \\
& =10.891 .458,33
\end{aligned}
$$

c. $\mathrm{Pd}=\mathrm{TR}-\mathrm{TC}$

$$
\begin{aligned}
& =18.746 .000-10.891 .458,33 \\
& =7.854 .541,67
\end{aligned}
$$

Tabel 12. Pendapatan Usahatani Kentang di Desa Sinsingon

\begin{tabular}{llc}
\hline No & Uraian & Rata-Rata Per Petani (Rp) \\
\hline 1 & Penerimaan & 18.746 .000 \\
2 & Biaya & $10.891 .458,33$ \\
3 & Pendapatan & $7.854 .541,67$ \\
\hline
\end{tabular}

Sumber : Diolah dari data primer, 2019.

Tabel 12 menunjukkan bahwa, pendapatan yang diperoleh oleh usahatani kentang di Desa Sinsingon Kecamatan Passi Timur yaitu sebesar Rp. 7.854.541,67-/Petani. Dari data tersebut, dijelaskan bahwa total penerimaan lebih besar dari pada total biaya yang dikeluarkan.

\section{Hasil Analisis Return Cost Ratio}

Untuk melihat tingkat keuntungan ekonomis usahatani kentang di Desa Sinsingon dapat diketahui dengan menggunakan Analisis Return Cost Ratio. Analisis R/C adalah perbandingan antara penerimaan dan biaya.

$$
\begin{aligned}
\mathrm{a} & =\mathrm{R} / \mathrm{C} \\
& =18.746 .000 / 10.891 .458,33 \\
& =1,72
\end{aligned}
$$

Nilai $\mathrm{R} / \mathrm{C}$ ratio $=1,72$ yang telah diperoleh tersebut mempunyai arti bahwa usahatani kentang di Desa Sinsingon, Kecamatan Passi Timur, Kabupaten Bolaang Mongondow dalam satu kali proses produksi menguntungkan.

\section{KESIMPULAN DAN SARAN}

\section{Kesimpulan}

Berdasarkan hasil penelitian, maka dapat disimpulkan bahwa usahatani kentang di Desa Sinsingon menguntungkan dilihat dari besarnya pendapatan per petani rata-rata adalah Rp. 7.854.541,67 dan ratio atau penerimaan dan pengeluaran $(\mathrm{R} / \mathrm{C})$ lebih besar dari satu. 


\section{Saran}

Berdasarkan kesimpulan maka dapat dikemukakan saran yaitu petani di Desa Sinsingon tetap memaksimalkan dan mempertahankan usahatani kentang serta lebih meningkatkan pendapatan dalam berusahatani kentang.

\section{DAFTAR PUSTAKA}

Daniel, Moehar. 2002. Pengantar Ekonomi Pertanian. Bumi Aksara. Jakarta.

Duriat, 2006. Penerapan Teknologi PHT pada Tanaman Kentang. Balai Penelitian Tanaman Sayuran. Bandung.

Kartawi. 2003. Prinsip Ekonomi Pertanian. PT. Rajagrafindo Persada, Jakarta. 